\title{
India's Geologists
}

$\mathrm{T}$ HE thirty-first annual presidential address to the Mining and Geological Institute of India, delivered in Calcutta by Dr. C. S. Fox, on January 3 last, deals with the "Story of Geology in India and the Evolution of the Geological Survey of India". It is of the nature of an index of all the officers concerned, marshalled in order with the precision of a "Civil List", but gives no connected account of their labours in the slow preparation of the geological maps of the Indian Empire, or of their influence on the growth of geological knowledge in general.

Brief introductory remarks on prehistory and a summary of the scanty data on medieval mining are followed by references to some of the topographical surveyors of the East India Company and the geologists who occasionally accompanied them.

The question of domestic coal supplies led to the appointment of a committee by Lord Auckland's administration exactly a century ago, but it was not until 1845, after experimenting with imported miners, that the Court of Directors in London was recom. mended to undertake "a Geological Survey of the Coal Formation of India". D. H. Williams, then mapping in South Wales, was engaged and sent out to Bengal, the first of a succession of more than a hundred geologists who have since found employment under the Government of India. He examined the Raniganj and Ramgarh fields, and moving on to Karanpura, died of malaria in 1848. Dr. J. McClelland, secretary of the Coal Committee, continued the programme outlined by Williams and submitted the first annual report of the Geological Survey of India for 1848-49.

The creation of the Survey as a separate entity really dates from the arrival of Dr. T. Oldham, formerly professor of geology in Trinity College, Dublin, in 1851. He found "that the establishment of the Geological Survey then consisted of one peon and one writer, with no European assistant, and no preparation for any field work. The few existing records were kept in a box in a small room in the Surveyor-General's Office". Dr. Oldham soon acquired suitable professional help, and retiring after twenty-five years' service in 1876, had the satisfaction of leaving an efficient staff of fifteen geologists, and of having founded the publications of the Department-Memoirs (1856), Palceontologia Indica (1861), Records (1867) -in their permanent form. He also commenced the training of Indian apprentices, the forerunners of the majority of the officers to-day. Malaria and other tropical diseases taxed the ranks of the pioneers severely ; of thirty-nine individuals who served up to the end of 1876 , thirteen died on duty, three were compelled to resign through illhealth and seven transferred to less exacting occupations.

The year 1902 marks, in the opinion of Dr. Fox, the closing stage in the construction of the Survey, and in the intervening years, three directors had followed the first: H. B. Medlicott (1876-87), coeditor with W. T. Blanford of the "Manual of the Geology of India" (1879) ; W. King, discoverer of the Singareni coalfield ; and C. L. Griesbach (1894-1903), known as an explorer of Afghanistan, Persia and Turkestan.

During the directorship of Sir Thomas Holland (1903-10), the academic aspects of Indian geology continued to receive full attention and the study of the country's mineral resources assumed great importance. The methods of collection and publication of statistical information were reorganised; the rules relating to prospecting and exploitation of the State-owned mineral deposits of British India were overhauled, and a series of researches initiated which have led to some of the existing ore-mining and metallurgical industries.

Under Sir Henry Hayden (1910-21), joint author with Sir Sidney Burrard of "A Sketch of the Geography and Geology of the Himalaya Mountains and Tibet", the Survey, with twenty gazetted officers, was stronger than it had ever been. Following the diversion of its routine activities to martial needs during the War, its cadre was increased to thirty-six in 1919, actual appointments being delayed until demobilisation supplied suitable recruits. Its normal duties were now resumed; surveying unmapped regions, re-examining important tracts, and attending to the increasing number of economic problems which the geologist has to solve. Thus it continued through the directorship of Sir Edwin Pascoe (1921-32), until under retrenchment orders, ten officers, including some of the most experienced, were retired and some of the junior ones reduced to a lower grade. This action recalls the statement of Medlicott, the second director, in 1881, that the Government geologist "is instituted more as a concession to what seems but a rising fashion, than from any faith in his knowledge or any understanding of his functions".

Sir Lewis Fermor directed operations from 1932 until 1935 and was succeeded by Dr. A. M. Heron, who, with twenty-seven years' field work to his credit, holds the Department's records for mapping and for the extent of area covered. The Survey is now entering another phase of its existence, in which a growing burden of responsibility must be shouldered by Indians themselves, for they now form more than half the diminished staff. To them descends by right the tradition of successful accomplishment, and they undoubtedly possess the ability to hand it on worthily.

Dr. Fox's list is limited to official geologists, but there have also been many amateur workers in India, as for example, Lieut.-General C. A. McMahon, the petrologist. The geologists attached to various oil and mining companies are responsible for much detailed and specialised work. Again, a high position must be reserved for the distinguished palæontologists of Britain, France, Austria and India, who, from the days of T. H. Huxley to the present time, have made so many invaluable contributions to the Palocontologia Indica. With these exclusions remedied, Dr. Fox's address will save much searching of archives, if the impressive story of the rise and progress of geology in India is ever written.

Dr. Fox is the author of a series of recent memoirs on the coalfields of India, and his address concluded with another timely warning of the perilously small reserves of good quality coking coals, and of the waste entailed by existing mining methods. 